Scientiae Educatia: Jurnal Pendidikan Sains Vol 6 (2): 166-181

DOI: http://dx.doi.org/10.24235/sc.educatia.v6i2.1743

Published by Tadris IPA Biologi, IAIN Syekh Nurjati Cirebon, Indonesia. p-ISSN 2303-1530, e-ISSN 2527-7596

SCIENTIAE EDUCATIA: JURNAL PENDIDIKAN SAINS

journal homepage: www.syekhnurjati.ac.id/jurnal/index.php/sceducatia

www.syekhnurjati.ac.id/jurnal/index.php/sceducatia/article/view/1743

\title{
Identifikasi Kerusakan Lahan Untuk Produksi Biomassa
}

\author{
Andrianto Kusumoarto $^{\text {a }}$, Kristiyanto ${ }^{\text {bx }}$, Hermantyo ${ }^{c}$ \\ a Progam Studi Arsitektur, Universitas Indraprasta PGRI, Jakarta, 12530, Indonesia \\ b Program Studi Pendidikan Biologi, Universitas Indraprasta PGRI, Jakarta, 12530, Indonesia \\ c PT. Shiddiq Sarana Mulya, Konsultan Sumberdaya Lahan, Jakarta, 12440, Indonesia
}

${ }^{x}$ Corresponding author: Jl. Nangka No. 58 C, Tanjung Barat, Jagakarsa, Jakarta Selatan, 12530, Indonesia. E-mail addresses: kristiyanto94@gmail.com

\begin{tabular}{|c|c|}
\hline article info & $\mathbf{a} b \mathbf{b} \mathbf{c} \mathbf{a} \mathbf{t}$ \\
\hline $\begin{array}{l}\text { Article history: } \\
\text { Received: } 3 \text { August } 2017 \\
\text { Received in revised form: } 13 \\
\text { November } 2017 \\
\text { Accepted: } 12 \text { December } 2017 \\
\text { Available online: December } 2017 \\
\text { Keywords: } \\
\text { Ecological Function } \\
\text { Biomass Production } \\
\text { Geography Information System } \\
\text { (SIG) } \\
\text { Soil Destruction }\end{array}$ & $\begin{array}{l}\text { IDENTIFICATION OF LAND DAMAGE FOR BIOMASS PRODUCTION. The soil has } \\
\text { limited resources and always has human pressured led to damage or disturbance, as } \\
\text { accumulate processes of chronic anthropogenic pressures or it activities has more unfriendly. } \\
\text { Therefore restoration processes soil ecological function develop, in increasing of biomass } \\
\text { production has very important for wellbeing. Aim this research to identification and analysis } \\
\text { of soil conditions of vulnerabilities, and it used to methods based to SK Dirjen RRL No. } \\
\text { 041/Kpts/V/1998 or law of government RI No. } 150,2000 \text { of year, and used or applied to } \\
\text { geography system information (SIG) approach. This research result of showed has } \\
\text { potentially of damage or disturbance of soil in Kramatmulya subdistrict, Kuningan, West } \\
\text { Java, Indonesia has examples in Pejambon villages of } 1,2 \text {, and } 3 \text { area, which is differences } \\
\text { of the potential soil damage (Low, medium, and high). it has based on permeability aspect, } \\
\text { which in Pejambon } 1 \text { area has high damage categories by } 12,76 \text { value cm/hours, then Ph } \\
\text { (H20) Pejambon } 2(4,23) \text { and } 3 \text { (4,19) value, which has of high damage categories, and DHL } \\
\text { in Pejambon } 1 \text { (16,00), } 2 \text { (19,00), and } 3 \text { ( } 47,00) \text { value has high damage to categories. } \\
\text { Processing of evaluation and monitoring of soil management is very important, besides of } \\
\text { more increasing of human population number, of course, the need of space for fulfilling the } \\
\text { wellbeing human aspects. }\end{array}$ \\
\hline
\end{tabular}

Fungsi Ekologi

Kerusakan Tanah

Produksi biomassa

Sistem Informasi Geografi (SIG)

\begin{abstract}
Tanah maupun lahan merupakan sumber daya yang terbatas dan senantiasa mendapatkan tekanan, yang mengarah pada kerusakan, akibat akumulasi aktivitas masyarakat, yang semakin tidak ramah lingkungan. Mengembalikan maupun merestorasi fungsi ekologi tanah (lahan), dalam rangka meningkatkan produksi biomassa menjadi penting, dalam memenuhi hajat hidup masyarakat banyak. Tujuan penelitian ini, mengidentifikasi dan menganalisis kondisi lahan, yang rentan dengan kerusakan. Metode yang digunakan untuk penilaian tingkat kekritisan lahan. Berdasarkan pada SK Dirjen RRL No. 041/Kpts/V/1998 atau Perpem RI No. 150 tahun 2000 (Kriteria baku kerusakan tanah), serta pendekatannya dengan menggunakan sistem informasi geografi (SIG). Hasil penelitian ini, menunjukkan bahwa, potensi kerusakan lahan yang terjadi di Kecamatan Kramatmulya, Kuningan, Jawa Barat, Indonesia, tepatnya di area Desa Pajambon 1, 2, dan 3, memiliki tingkatan kerusakan lahan yang berbeda-beda (ringan, sedang, dan berat), hal ini berdasarkan pada aspek Permeabilitas, yaitu Pejambon 1 mengalami kerusakan dengan nilai $12,76 \mathrm{~cm} / \mathrm{jam}$, kemudian berdasarkan $\mathrm{pH}$ (H20), Pejambon 2 dan 3 dalam kategori rusak berat dengan $\mathrm{pH}$ 4,23 dan 4,19, dan berdasar pada DHL Pejambon 1, 2, 3 dalam ketegori rusak berat, sehingga memonitoring dan mengevaluasi penggunaan lahan menjadi penting, seiring dengan makin meningkatnya jumlah populasi manusia, yang tentunya membutuhkan ruang untuk memenuhi atau mencukupi hidup secara layak.
\end{abstract}

2017 Scientiae Educatia: Jurnal Pendidikan Sains

\section{Pendahuluan}

Tanah maupun lahan merupakan sumber daya alam, yang terbatas dan senantiasa mendapatkan tekanan yang semakin besar, yang merupakan konsekuensi akumulasi aktivitas masyarakat (Anthropogenic), disamping aspek alam (Natural aspects) yang terus mengalami 
perubahan secara fluaktuatif dan dinamis (Arisandi et al, 2015). Oleh karena itu, kerusakannya perlu terus dipantau dan dikendalikan secara tepat dan efektif, menurut Setyaningrum (2015) mengungkapkan, bahwa upaya yang perlu dilakukan untuk menjaga dan meningkatkan produktivitas sumber daya tanah, satu diantaranya dengan pemberian bahan organik. Mengingat aktivitas penggunaan lahan untuk pertanian, yang berlangsung di Kabupaten Kuningan sangat intens dalam meningkatkan kesejahterahan masyarakatnya, maka kesuburan tanah dan produktivitasnya harus dipertahankan, disamping ditingkatkan, dimana Maier et al, (2015) menyebutkan bahwa kualitas tanah mampu mencerminkan tingkat produktivitas dalam mendorong pembangunan (pertanian), yang tentunya hal ini bergantung pada kemampuan masyarakat dalam mengimplementasikannya, secara berkelanjutan dengan mengelola lahan dengan baik. Hal ini, juga sebagai respon atas semakin kompleksnya permasalahan yang muncul ditengah-tengah masyarakat dalam meningkatkan produktivitas lahan untuk memenuhi pangan maupun non pangan (Laurance Sayer, 2014; Fahma \& Kristiyanto 2016)

Meningkatnya aktivitas masyarakat dalam memanfaatkan tanah maupun sumber daya alam/lahan, dalam berbagai kegiatan lain untuk meningkatkan produksi biomassa, terkesan masih bersifat eksploitatif dan tidak terkendali, yang secara langsung dapat mengakibatkan kerusakan lahan untuk produksi biomassa. Fenomena tersebut dapat mempengaruhi penurunan produksi biomassa, sehingga dapat menurunkan mutu atau kualitas kapasitas tanah (Ecosystem services) secara degradatif, yang akhirnya dapat mengancam kelangsungan kehidupan manusia dan mahluk hidup lainnya (Zhu, 2015). Oleh karena itu, pencegahan kerusakan lahan untuk produksi biomassa adalah sebuah upaya strategi untuk mempertahankan atau melestarikan kondisi tanah melalui cara-cara yang tidak memberi peluang berlangsungnya kerusakan lahan,, pengelolaannya dengan ramah lingkungan dan tidak memberi peluang berlangsungnya kerusakan lahan di masa depan.

Penanggulangan kerusakan lahan merupakan bagian dari upaya yang terus dilakukan untuk menghentikan atau minimalisir meluasnya kerusakan lahan. Proses pemulihan (restorasi maupun konservasi) kondisi tanah atau lahan merupakan sebuah upaya untuk mengembalikan kondisi tanah ke tingkatan, yang lebih optimal atau tidak rusak yang implementasinya, mampu memenuhi siklus kehidupan secara ekologis dan berkelanjutan pada ekosistem tanah (Mcbratney, 2014). Peran aktif masyarakat secara sadar atau ramah lingkungan, menjadi penting dalam mengevaluasi dan mengimplementasikan proses pengelolaan lahan secara 
konservatif, baik dari aspek tanah maupun air di dalamnya (Teshome et al, 2014; Francis and Porter, 2011).

Mengacu pada kompleksitas permasalahan dan strategis pengelolaan yang ramah lingkungan diatas, penelitian ini mencoba mengidentifikasi maupun mengklasifikasikan area yang berpotensi mengalami atau rentan dengan kerusakan lahan untuk produksi biomassa, satu diantaranya dengan memetakan sebaran kondisi dan status kerusakan lahan untuk produksi biomassa, secara informatif, akurat, dan berbasis sistem informasi geografi (SIG). Berdasarkan pada permasalahan tersebut, diperlukan data dan informasi kerusakan lahan yang terjadi, dengan cara melihat dinamika produktivitas biomassa di beberapa kawasan Kabupaten Kuningan, tepatnya di Desa Pejambon 1, 2, dan 3, secara komprehensif dan integratif, baik secara ekologis maupun non ekologis.

Adapun hasil dan manfaat penelitian ini, dapat mendukung atau menunjang dalam mengidentifikasi dan mengiventarisasi tingkat keragaman potensi maupun kerentanan lahan, yang terjadi di Desa Pejambon (1, 2, dan 3). Adapun tujuan penelitian ini, dapat digunakan untuk mendukung dalam memformulasikan sebuah strategi atau solusi alternatif, dalam mengantisipasi maupun mengendalian kerusakan lahan, secara lebih efektif dan efisien, dengan berkelanjutan dan berbasis masyarakat, yang mengarah pada paradigma "Sustainable agriculture" (Akowuah, 2012).

\section{Metode Penelitian}

Lokasi penelitian berada di kawasan Kabupaten Kuningan, tepatnya di Desa Pejambon 1, 2, dan 3 dengan titik koordinat lokasinya, (a) Pajambon 1 (BT 108²6.883' dan S 0656.394'LS); (b) Pajambon $2\left(108^{\circ} 27.026^{\prime}\right.$ BT dan S 06 56.414'LS), dan (c) Pajambon 3 (108²7.737' BT dan $06^{\circ} 56.265^{\prime}$ LS). Penelitian ini, dilakukan selama 3 bulan dari bulan Desember 2016 sampai bulan Februari 2017. Penelitian ini, dilakukan melalui atau dengan pendekatan survai maupun observasi, yaitu mengamati dan mengumpulkan data-data biofisik di daerah penelitian, sedangkan penentuan dalam plot pengamatan (titik pengamatan), ditentukan berdasarkan pada hasil overlay antara peta tanah, peta penggunaan lahan dan peta kelas lereng. Overlay peta tersebut, dapat menghasilkan beberapa satuan lahan, yang selanjutnya tiap satuan lahan yang diperoleh dijadikan plot pengamatan, disamping data biofisik, kemudian di cocokkan di lapangan dengan menggunakan Global Positioning System (GPS). 
Penilaian tingkat kekritisan lahan dilakukan berdasarkan pada dokumen Petunjuk Teknis Penyusunan Data Spasial Lahan Kritis tahun 2004 oleh Direktorat Jenderal Rehabilitasi Lahan dan Perhutanan Sosial (RLPS) dan Surat Direktur Jenderal RLPS No. S. 296/V-SET/2004 Tanggal 5 Oktober 2004. Adapun teknik analisis yang digunakan dalam penelitian ini, berdasarkan pada metoda overlay dan hasil survai lapang, dengan beberapa data spasial yang merupakan parameter penentu kekritisan lahan.

Parameter penentu kekritisan lahan tersebut, berdasarkan SK Dirjen RRL No. 041/Kpts/V/1998, meliputi kondisi tutupan vegetasi, kemiringan lereng, tingkat bahaya erosi dan singkapan batuan (outcrop), dan kondisi pengelolaan (manajemen), sehingga secara detailnya dapat dilihat pada Gambar 1, baik secara kuantitatif maupun kualitatifnya. Kelima faktor tersebut, masing-masing diberi skor 1-5 (sangat buruk-sangat baik), kemudian diberi pembobotan sesuai dengan pengaruh dari masing-masing faktor terhadap penyebab kerusakan lahan, yaitu diantaranya (a) kemiringan lereng 5\%, (b) tingkat kerusakan lahan (c) tingkat bahaya erosi 5\%, dan (d) pola pengelolaan dan sebaran jenis tanaman dengan pola pengelolaan (manajemen). Berdasarkan analisis potensi kerusakan dengan teknik overlay, maka potensi kerusakan lahan dapat dikelompokkan atau diklasifikasikan ke tingkat kerusakan ringan, sedang, dan tinggi.

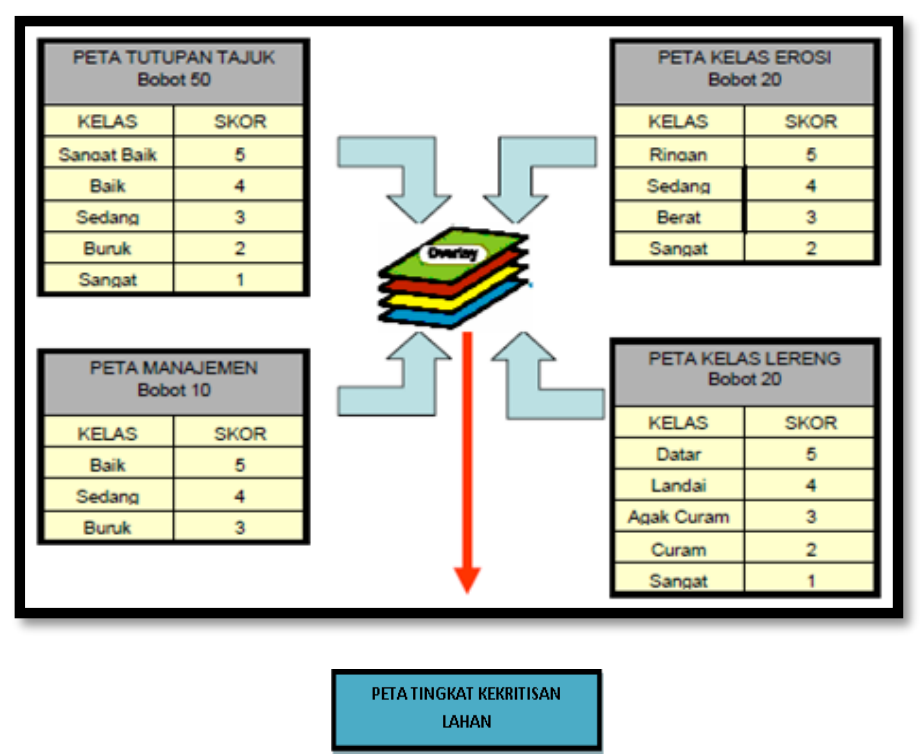

Gambar 1. Tahapan dan skoring analisis lahan kritis

\section{Hasil dan Pembahasan}

Secara umum kawasan di Kabupaten Kuningan Jawa Barat, secara klimatologi termasuk ke dalam wilayah beriklim tropis termasuk pada tipe iklim $A f$ (basah sepanjang tahun, karena curah 
hujan $60 \mathrm{~mm}$ ) (Arifah, 2016), dengan rata-rata suhu udara sepanjang tahun 2014 mencapai $27,3^{\circ} \mathrm{C}$, suhu minimum cenderung sebesar $23^{\circ} \mathrm{C}$, sedangkan suhu maksimum tertinggi mencapai $32^{\circ} \mathrm{C}$ (BPS Kabupaten Kuningan, 2015). Adapun kondisi curah hujan tertinggi di Kabupaten Kuningan selama tahun 2014, mencapai puncaknya pada bulan April, yaitu mencapai rata-rata $271,5 \mathrm{~mm}$, dan curah hujan terendah mencapai rata-rata $26,32 \mathrm{~mm}$, yaitu terjadi pada bulan Oktober (BPS Kabupaten Kuningan, 2015). Adapun rerata curah hujan yang terjadi kawasan Kecamatan Kramatmulya, berkisar antara 2.200 mm/tahun -2.600 mm/tahun. Lokasi yang menjadi objek penelitian adalah Desa Pejambon 1, 2, dan 3.

Desa Pejambon (1, 2, dan 3) merepresentasikan realita empiris yang menggambarkan kondisi lahan yang telah dikelola dan dimanfaatkan masyarakat, dimana hampir sebagian besar masyarakat ini, memanfaatkan lahan untuk perkebunan, pertanian, peternakan, dan bahkan lahan pertambangan yang telah dilakukan secara massif dan destruktif. Pola pengelolaan tersebut, secara akumulatif telah menyebabkan kerusakan lahan, yang secara distributif kondisi kerusakan lahan ini, dapat dilihat pada Gambar 3, dimana akumulasi perhitungannya diperoleh dari berbagai parameter yang digunakan untuk mengkalkulasi tingkat kerusakan lahan yang telah terjadi.

Hasil pengukuran diperoleh (a) berdasar permeabilitas, yaitu Pejambon 1 mengalami kerusakan dengan nilai 12,76 cm/jam, (b) berdasarkan $\mathrm{pH}(\mathrm{H} 20)$, Pejambon 2 dan 3 dalam kategori rusak berat dengan $\mathrm{pH}$ 4,23 dan 4,19, dan (c) berdasar pada DHL Pejambon 1, 2, 3 dalam kategori rusak berat. Beberapa komponen dari beberapa parameter dalam mengklasifikasikan distribusi maupun nilai kerusakan lahan ini, menjadi indikator (kuantitatif maupun kualitatif) penting dalam menentukan kerusakan lahan yang telah terjadi dengan melihat aspek atau faktor dominan, yang mendorong terjadinya laju kerusakan tanah atau lahan tersebut. Fenomena tersebut, secara signifikan dapat berkaitan dengan berbagai aspek, yaitu (a) tingkat kemiringan lahan, (b) tingkat erosi, atau (c) jenis tanah yang rentan terhadap erosi, disamping (d) kondisi curah hujan yang tinggi, dengan kelas lereng yang dominan diatas $8 \%$, sedangkan (e) aspek manusia terkait dengan masalah (1) kepemilikan lahan, (2) sistem pengelolaan lahan yang tidak sesuai dengan kaidah konservasi tanah dan air, (3) kondisi sosial, dan (4) ekonomi (Agarwala et al, 2014), disamping masih banyaknya praktek-praktek pengelolaan dan pengembangan lahan pertanian yang tidak sesuai dengan kemampuan ataupun kesesuaiannya, yang dilakukan masyarakat. 
Hal tersebut diatas, bertentangan atau bertolak belakang dengan program maupun kebijakan yang telah termaktub dalam Peraturan Daerah Kabupaten Kuningan No. 7 tahun 2015, yang berkaitan dengan perlindungan lahan pertanian pangan berkelanjutan, baik secara sosial, ekonomi, maupun ekologi. Hal ini, tentunya menjadi pedoman bagi setiap pelaku (masyarakat) maupun pemerintah setempat, dalam menjaga dan melestarikan lahan pertanian secara berkelanjutan, walaupun pada di sisi lain belum menampakkan sinergitas yang konsisten dan berkesinambungan (Redpath et al, 2013). Oleh karena itu, perlu adanya sebuah terobosan baru yang dinamis dan sinergis, dalam membangun model pertanian yang cerdas ekologis, yang berbasis konservatif (Govers et al, 2017).

\subsection{Tingkat Kemiringan Lahan}

Pada aspek topogeografis, tingkat kemiringan lahan di wilayah penelitian diperoleh dengan menggunakan Peta Rupa bumi skala 1:50.000, dengan tampilan utuh dari lembar-lembar peta tersebut, diperoleh hasil Peta Kelas Lereng pada lokasi penelitian. Hasil proses tersebut, menunjukkan bahwa tingkat atau kelas lereng lokasi penelitian pada skala tingkat landai, hingga agak curam. Kemiringan lahan tersebut merupakan salah satu diantara faktor-faktor yang berkontribusi terjadi erosi tanah atau lahan, selain faktor iklim, tipe tanah, dan curah hujan (Asy Syakur, 2011). Hal ini harus menjadi pertimbangan dalam mengelola dan memanfaatkan kondisi lahan ke depan.

Adapun peta sebaran kemiringan lahan detailnya terdapat pada Gambar 2. Desa Pejambon, Kecamatan Kramatmulya, memiliki luasan 16,53 ha (0-8\%), 32,06 ha (9-15\%), 18,09 ha (16$25 \%), 13,72$ ha $(26-45 \%)$, dan 7,31 ha $(>45 \%)$.

\subsection{Tingkat Erosivitas dan Erosi Lahan}

Permasalahan erosi bagian dari permasalahan ekologi yang akumulatif, yang belum banyak terantisipasi secara optimal dalam pengendaliannya, aspek topogeografi maupun aspek manusia menjadi pemicu timbulnya permasalahan, hal ini juga dikaitkan dengan bentuk atau karakteristik bentang lahan skala lokal (Montgomery, 2007). 


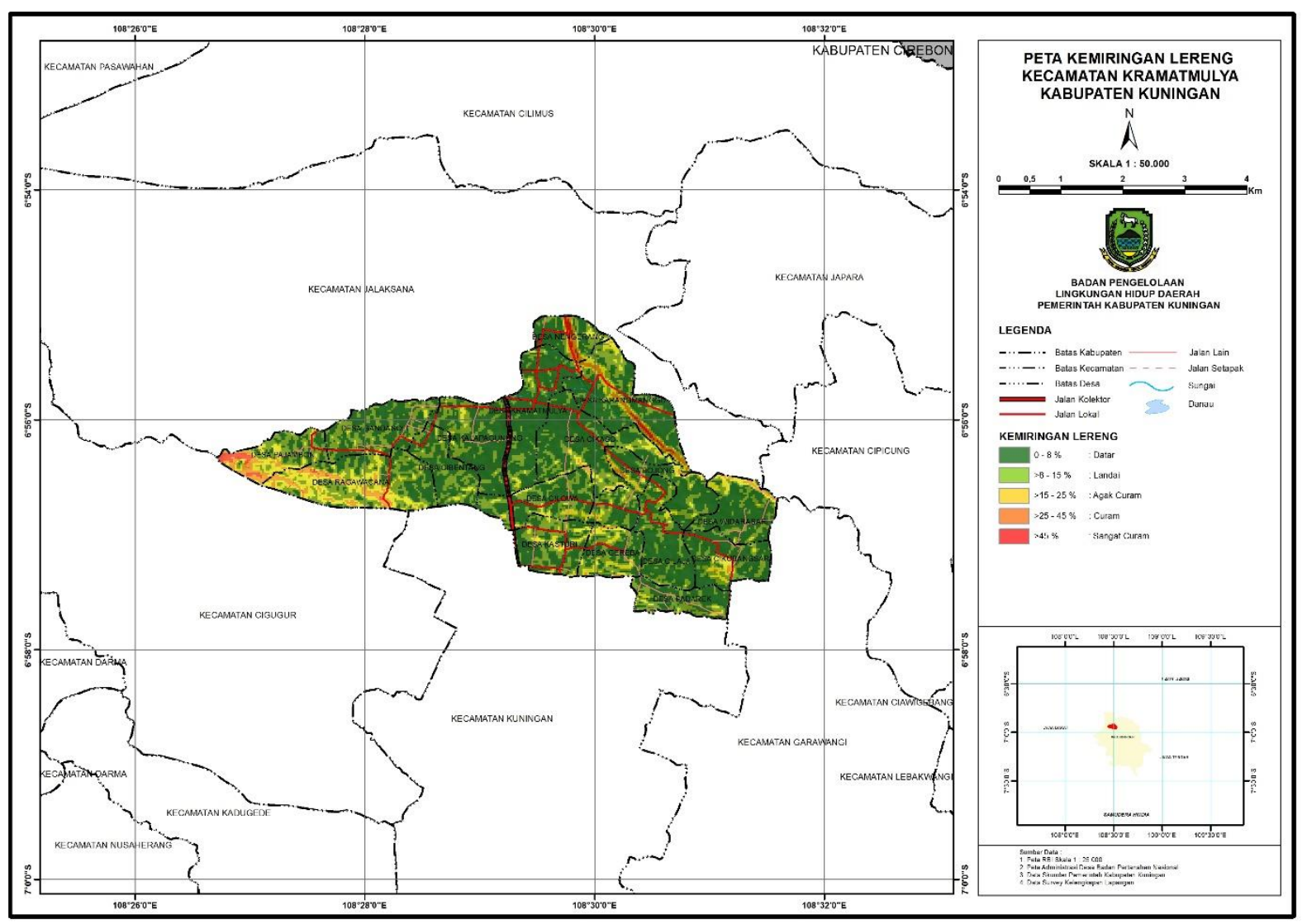

Gambar 2. Peta sebaran kelas lereng Kecamatan Kramatmulya

Parameter permeabilitas tanah atau derajat pelulusan air dapat menjadi indikator yang menunjukkan derajat pelulusan airnya rendah, sehingga menyebabkan air limpasan permukaan (run off) semakin meningkat, kemudian tingkat kerusakan lahan akibat erosi pun meningkat, dan berdampak pada kerusakan tanah. Fenomena tersebut, dapat dilihat bagaimana area Desa Pejambon 1, 2, dan 3, yang secara kuantitatif maupun kualitatif, di peroleh nilai erosivitas hujan dengan nilai akumulasi di Desa Pajambon, yaitu sebesar 129,92, kemudian nilai erodibilitas untuk titik sampel Pajambon $1(0,95)$, titik sampel Pajambon $2(0,76)$ dan titik sampel Pajambon $3(0,77)$, hal ini sangat berkorelasi dengan tingkat kerentanan erosi akibat adanya perubahan curah hujan (Mohamadi \& Kavian, 2015), walaupun di pihak lain, bahwa tipe atau karakteristik hujan dapat menjadi acuan bagaimana minimalisir kerusakan lahan (Land use) akibat curah hujan (Lima et al, 2013).

Berdasarkan pada hasil penelitian ini, bahwa kawasan Desa Pajambon, dalam ketegori kerusakan di atas ambang kritis atau dapat dikategorikan ke dalam kelas atau tingkatan kerusakan yang tinggi. Hal ini dapat dilihat dari aspek tingkat erosi, yaitu pada titik lokasi (1) 
Pajambon 1 dalam kategori erosi ringan (18,67 ton/ha/tahun), (2) Pajambon 2 lokasi dalam kategori kelas erosi berat (184,40 ton/ha/tahun), dan (3) Pajambon 3 dalam kategori kelas erosi sangat berat $(210,00$ ton/ha/tahun)

\subsection{Tingkat Kerusakan Lahan}

Kawasan Kabupaten Kuningan adalah kawasan yang masih memiliki banyak potensi sumber daya dengan luasan lahan yang masih luas dan hijau, dengan tingkat biodiversitas (flora maupun fauna) yang cukup tinggi. Potensi alam tersebut mulai terdegradasi oleh banyaknya aktivitas masyarakat dalam mengelola dan memanfaatkannya, satu diantaranya masih maraknya adanya kegiatan pertambangan (pasir, batu, maupun kapur). Kegiatan pertambangan tersebut, tidak hanya dilakukan di area hutan (Land cover), tetapi juga di area persawahan maupun dekat dengan area pemukiman (lihat gambar 3). Jenis kegiatan pertambangan ini, telah banyak menimbulkan kerusakan lahan atau menjadi ancaman terhadap tingkat biodiversitas flora dan fauna (Kumar, 2013). Oleh karena itu, perlu adanya evaluasi maupun monitoring secara berkelanjutan dan terintegrasi, dalam rangka menjaga dan melestarikan kekayaan flora atau tanaman untuk menunjang pengembangan kegiatan pertambangan yang lebih ekologis maupun non ekologis. Salah satunya dengan merestorasi dan mengkonservasi tanah, karena aspek ini satu diantara indikator penting, dalam menilai atau menunjang kapasitas ekosistem atau “Ecosystem functioning” (Costantini et al, 2016).

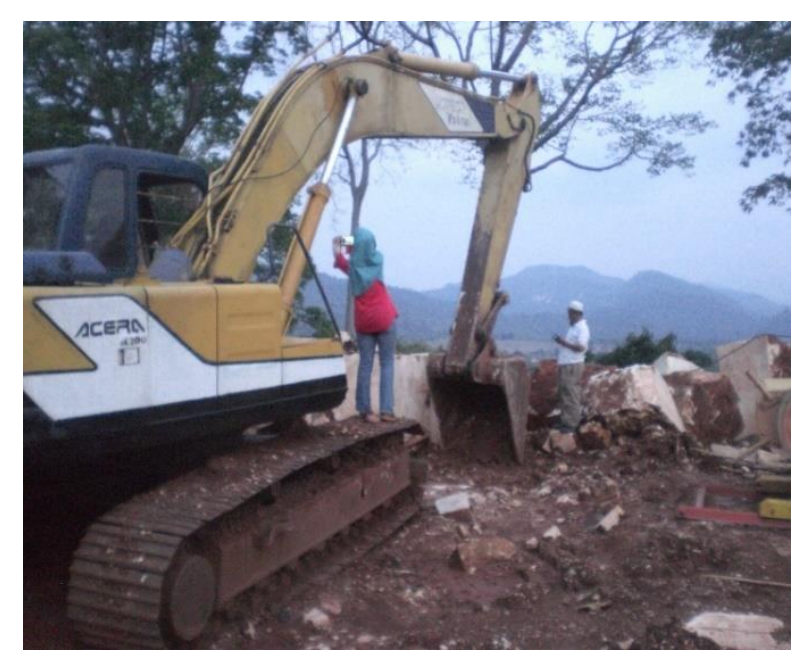

a.

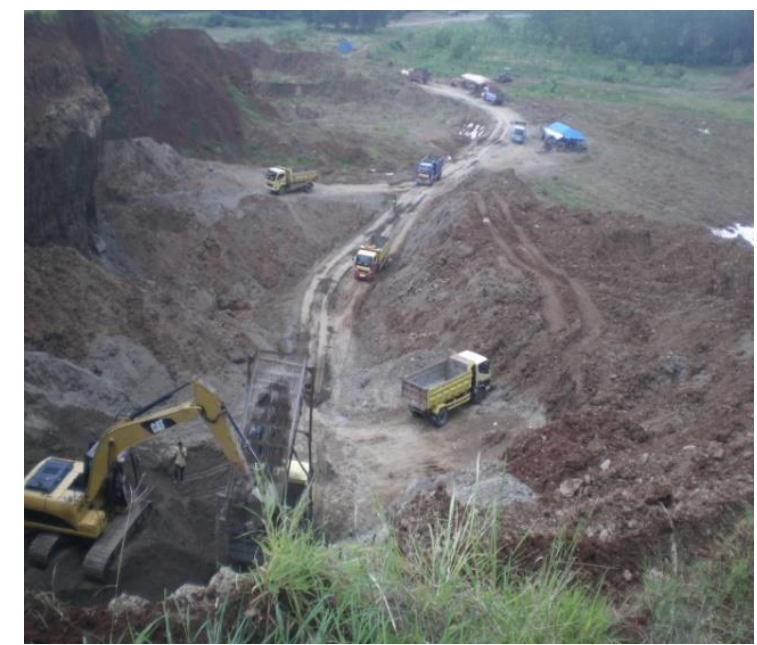

b.

Gambar 3. Jenis Kegiatan Pertambangan (a: Pertambangan Batu Kapur; b: Pertambangan Pasir dan Batu 
Dampak jangka panjang akibat kegiatan pertambangan (Gambar 3) secara akumulatif telah menyebabkan kerusakan permukaan lahan, yang mengarah pada adanya ketidakseimbangan ekosistem salah satunya terjadinya erosi akibat terdegradasi vegetasi permukaan (Berendse $e t$ al, 2015), fenomena ekologis ini dapat dilihat di wilayah bagian Barat, yaitu di kawasan Kecamatan Kramatmulya, dimana tingkat kerusakan lahannya tergolong tinggi (berat), tepatnya di Desa Pajambon 1, 2, dan 3, seperti yang telah disinggung pada alinea b diatas. Oleh karena itu, tipe penggunaan lahan hampir seluruhnya di dominasi dengan penggunaan lahan, (a) sawah irigasi, (b) sawah tadah hujan dan (c) permukiman/tempat kegiatan. Di samping itu, areanya memiliki tingkat kelerengan dengan kelas lereng $<8 \%$, sehingga karakteristik kondisi lahan tersebut, memiliki potensi atau rentan dengan kerusakan lahan, walaupun di pihak lain, masuk dalam kategori relatif ringan atau kecil.

Adapun luasan lahan yang mengalami kerusakan di Desa Pajambon secara umum, dapat diklasifikasikan (a) kerusakan ringan seluas 45,4 ha (51,6\%), (b) kerusakan sedang seluas 4,7 ha $(5,4 \%)$, dan (c) kerusakan berat seluas 37,7 ha $(42,9 \%)$. Adapun sebaran tingkat kerusakan lahan di kawasan Desa Pejambon 1,2, dan 3 tersebut, dapat di lihat pada peta gambar 4, dimana durasi maupun tingkat kerusakannya sangat berkorelasi dengan faktor tipe tanah maupun aspek topografi (Qiu et al, 2016).

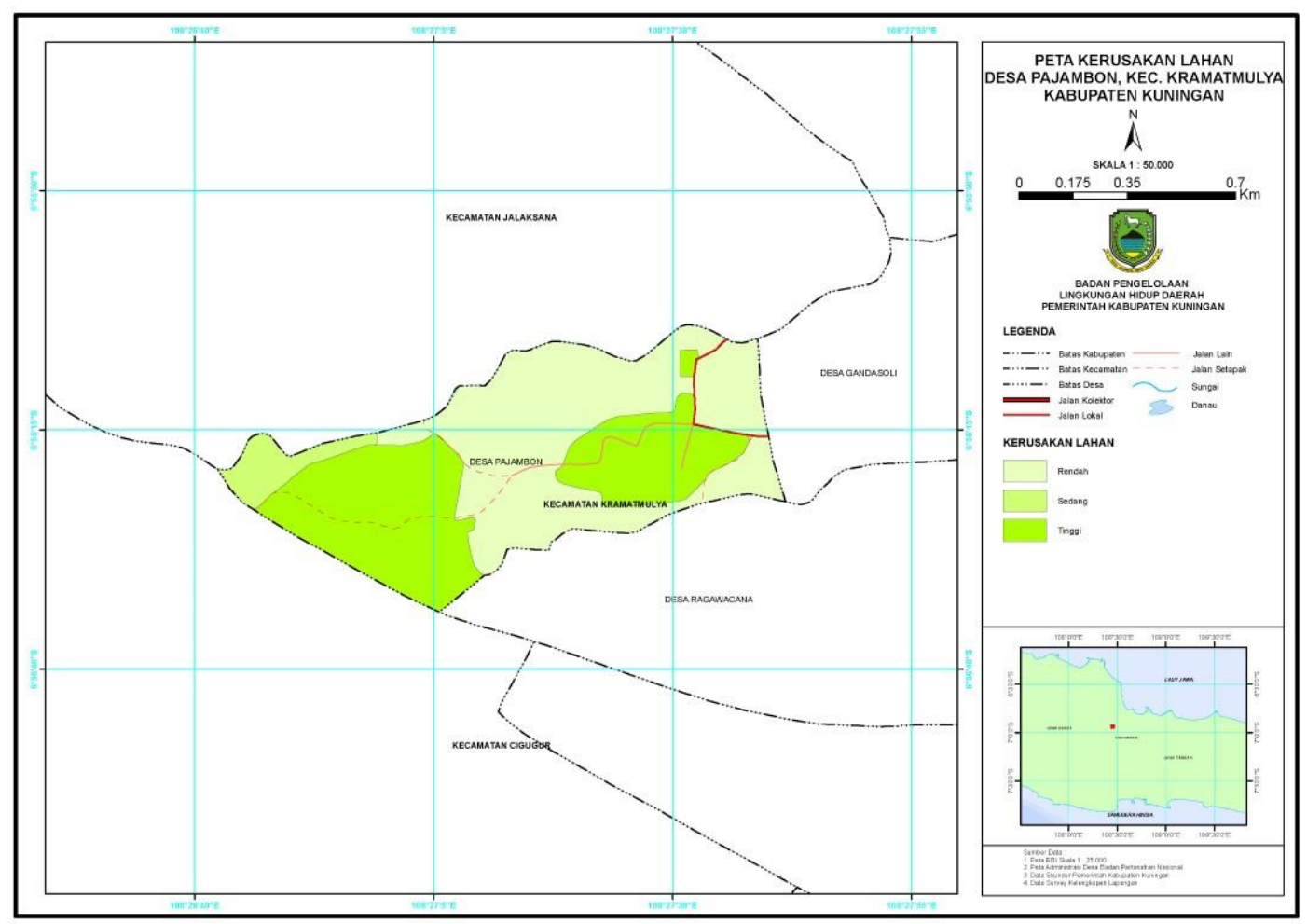

Gambar 4. Sebaran tingkat kerusakan lahan di Desa Pejambon, Kecamatan Kramatmulya 


\subsection{Pola Pengelolaan dan Sebaran Jenis Tanaman}

Mengelola dan memanfaatkan potensi sumber daya lahan (tanah), tentunya berdasarkan pada berbagai aspek topogeografis atau biogeografi, dimana pada alinea sebelumnya telah dijabarkan, bahwa kesesuaian lahan memiliki peran penting dalam meningkatkan optimalisasi produktivitas tanaman/pangan/maupun non pangan. Oleh karena itu, perlu adanya sebuah perencanaan yang tepat dan satu diantaranya sesuai dengan habitat atau kondisi lahannya (Pimentel Burgess 2013), walaupun di pihak lain, bahwa tingkat kelerengan pada suatu kawasan tertentu, berpengaruh pada kesesuaian jenis tanaman tertentu (pangan maupun non pangan), disamping pola konservasi yang dilakukan dan dikembangkan.

Berdasar panjang lereng (LS) diperoleh, bahwa pada titik sampel Pajambon 1 sebesar $(12,00)$, panjang lereng (LS) untuk titik sampel Pajambon 2 sebesar (12,00), dan panjang lereng untuk titik sampel Pajambon 3 sebesar $(9,5)$. Berdasarkan pada karakteristik tersebut, dapat diasumsikan secara teoris maupun empiris, hal ini dapat dikorelasikan dengan jenis tanaman maupun pola konservasi yang dapat dilakukan dan dikembangkan, yaitu pada titik sampel Pajambon 1 tersebar jenis tanaman hutan sekunder (nilai $\mathrm{C}=0,1$ ), titik sampel Pajambon 2 tersebar jenis tanaman kebun sayuran (nilai $\mathrm{C}=0,35$ ), dan titik sampel Pajambon 3 tersebar jenis tanaman kebun jambu (nilai $\mathrm{C}=0,5$ ). Oleh karena itu, teknik konservasi pada titik sampel Pajambon 1 adalah tanaman perkebunan dengan penutup tanah rapat (nilai $\mathrm{P}=0,1$ ), teknik konservasi di titik sampel Pajambon 2 adalah teras tradisional (nilai $\mathrm{P}=0,35$ ), dan teknik konservasi di titik sampel Pajambon 3 adalah teras tradisional (nilai $\mathrm{P}=0,35$ ).

Kawasan Kecamatan Kramatmulya secara geografis maupun topografis dapat di klasifikasikan sesuai dengan bentuk lahan, yang dapat dibagi menjadi beberapa jenis dalam penggunaan lahan berdasarkan bentuk lahan, yaitu (1) hutan rimba, (2) padang rumput, (3) perkebunan/kebun, (4) permukiman dan tempat kegiatan, (5) sawah, (6) sawah tadah hujan, (7) semak belukar, (8) tegalan/ladang, secara detailnya sebaran jenis penggunaan lahan dapat dilihat pada Gambar 5. 


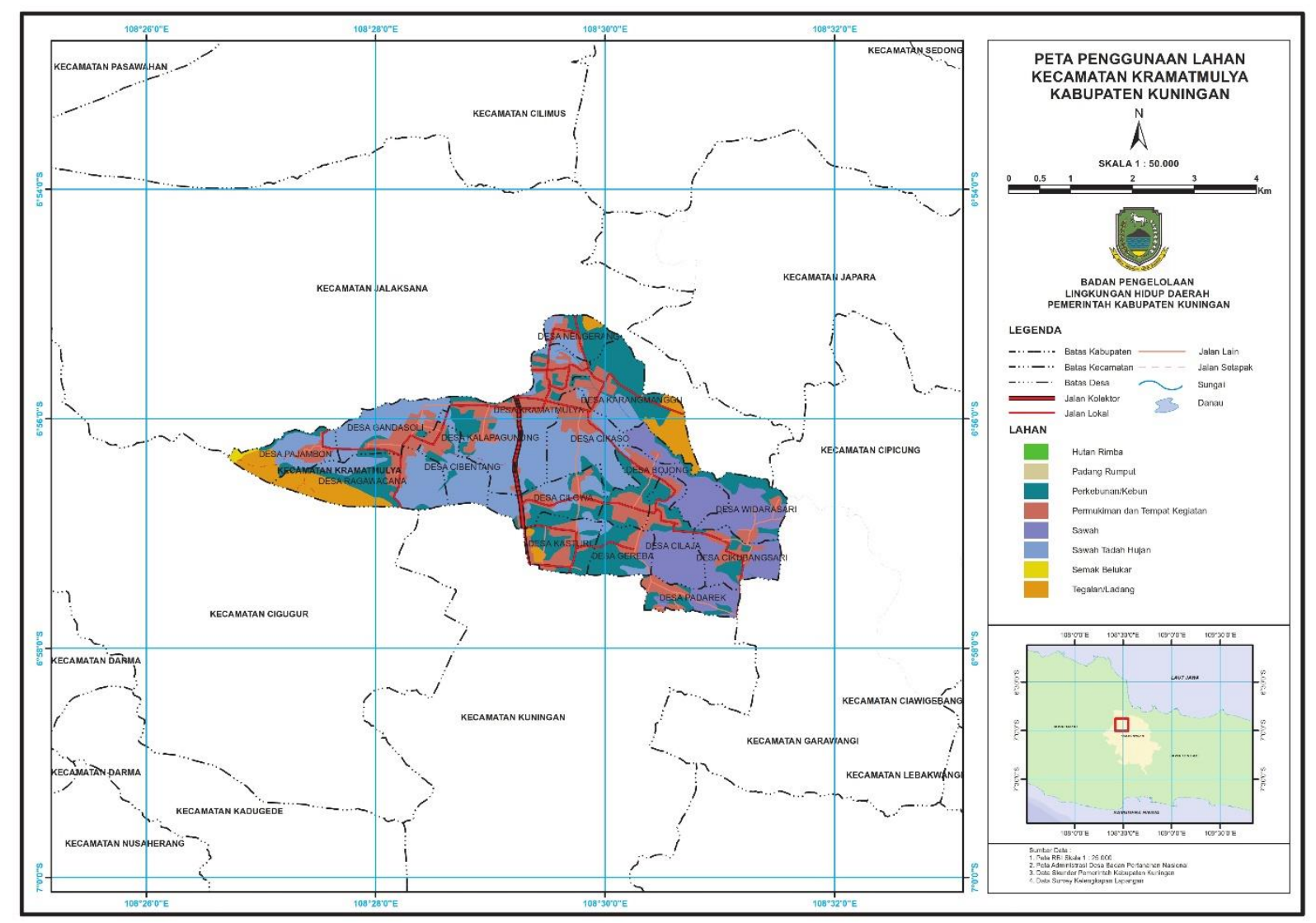

Gambar 5. Peta sebaran penggunaan lahan di Kecamatan Kramatmulya

Mengacu pada dinamika kompleksitas permasalahan lahan di area penelitian, dapat terkait dengan penyebab dan dampak kerusakannya, terutama di Desa Pejambon, dapat menjadi atau sebagai faktor tunggal maupun faktor sebab-akibat dan saling menguatkan. Sarah, Zhevelev, \& Atar (2015) mengungkapkan bahwa aspek Anthropogenic maupun populasi manusia yang terus mengalami peningkatan, hal ini tentunyadapat menjadi faktor utama, disamping terdapat aspek lain, baik faktor fisik lahan seperti aspek jenis tanah yang rentan terhadap curah hujan yang tinggi, seperti yang terjadi di Desa Pajambon 3, yang menunjukkan kategori kelas erosi sangat berat (210,00 ton/ha/tahun), hal ini juga dipengaruhi dengan tingkat kemiringan lereng (Karami, 2015). Di samping itu, juga dipengaruhi sistem pengelolaan lahan, yang masih jauh dari upaya ranah konservasi lahan, yang terlihat belum optimal, juga aspek ekonomi yang lebih menjadi prioritas utama selama ini. Tingkat kerusakan lahan juga, dapat dilihat dari aspek ketebalan solum, yang dapat menyebabkan tanah di bagian atas, banyak mengalami erosi, dan berdampak pada aspek solum tanah menjadi tipis, yang mengarah pada 
ketidakstabilan produksi pangan dan ancaman bagi keberlanjutan atau keberlangsungan lingkungan (Pimentel \& Burgess, 2013), bilamana tidak direspon secara baik dan cepat.

Pada aspek lain, tanah termasuk jenis yang baru terus berkembang, sehingga batuan induknya masih berada dekat permukaan. Oleh karena itu, solum tanah yang cenderung tipis menyebabkan tidak dapat berkembangnya perakaran tanaman, yang berakibat pada rendahya produktivitas tanaman, hal ini tidak terjadi di Desa Pejambon baik di titik 1, 2, dan 3, karena secara ilustratif dapat dilihat pada gambar 6 .

Pada Gambar 6 (di bawah) menunjukkan kondisi permukaan lahan, yang menunjukkan tumbuh kembangnya suatu jenis tanaman (herba maupun berkayu) dengan baik, secara ekologi, dimana kondisi tanah permukaannya menunjukkan tingkat keragaman jenis tanaman yang tinggi di dalamnya, sehingga tingkat kerusakan lahan bisa menjadi ringan atau kecil (Hilary Ford et al, 2016). Oleh karena itu, indikator vegetasi tersebut, dapat menjadi pemikiran bersama, bahwa dalam meningkatkan produktivitas biomassa lahan, bisa dilakukan tanpa harus merusak atau mengubah kondisi lahan secara massif dan destruktif (merusak), salah satunya dengan memperdayakan peran dan kontribusi masyarakat dalam mengelola lahan, secara mandiri dan berkelanjutan, baik secara ekologis maupun non ekologis, dalam implementasinya (Gunawan et al, 2013).
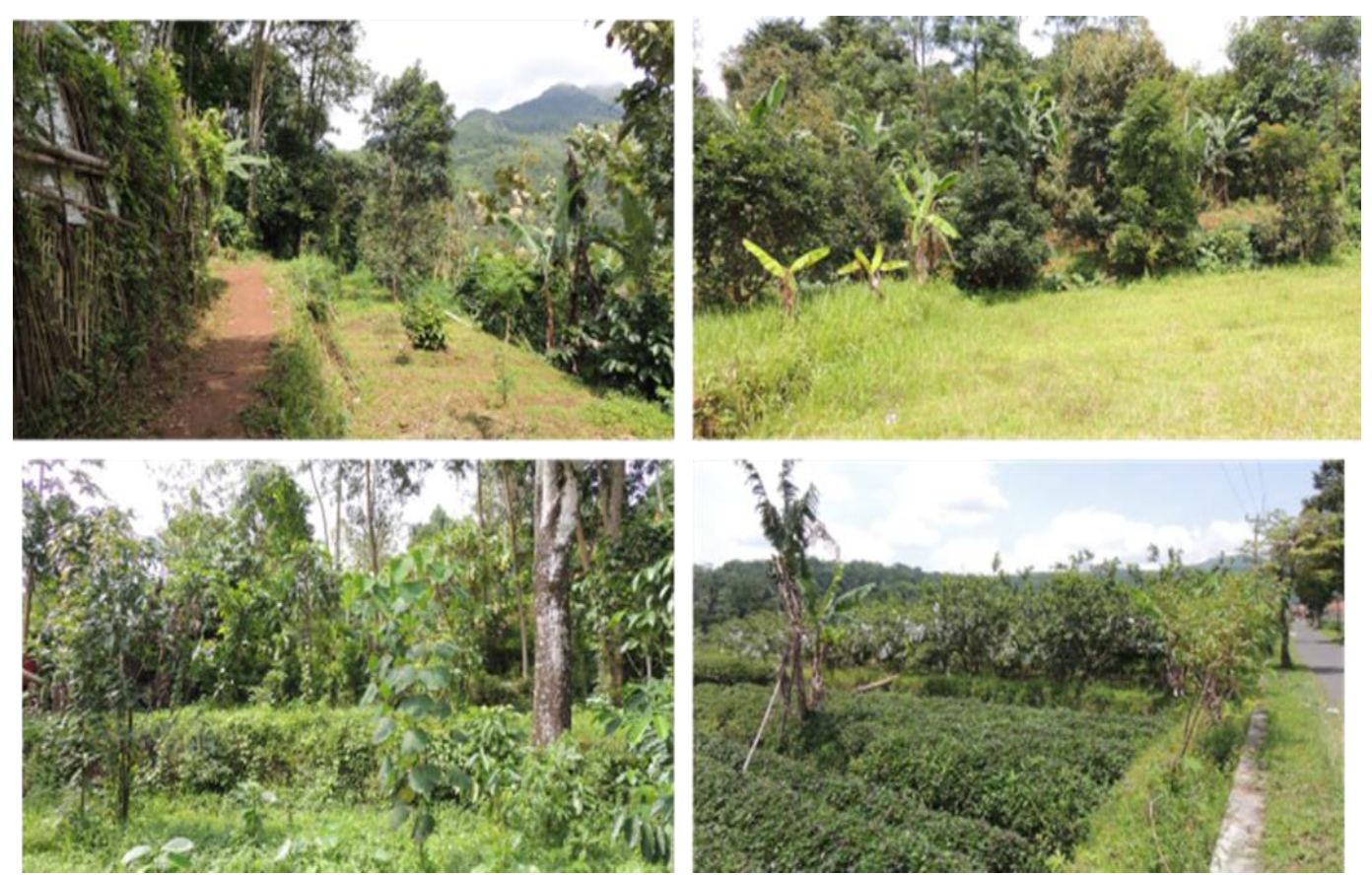

Gambar 6. Deskripsi visualisasi kondisi permukaan lahan (Tutupan lahan) di beberapa titik pengamatan Desa Pejambon, Kecamatan Kramatmulya 


\section{Simpulan}

Tingkatan kerusakan yang telah terjadi di Desa Pejambon dapat diklasifikasikan, yaitu (1) kerusakan ringan 51,6\%), (2) kerusakan sedang seluas 4,7 ha (5,4\%), dan (3) kerusakan berat seluas 37,7 ha $(42,9 \%)$. Kalkulasi tingkat kerusakan tersebut, kombinasi dari permasalahan ekologis maupun non ekologis yang terjadi, disamping aspek lainnya, seperti adanya dampak perubahan iklim, terkait dengan durasi dan intensitas curah hujan yang terlihat berubah secara ekstrim, sehingga menyebabkan erosi tanah, walaupun dengan tingkat kerusakan yang berbedabeda, di Desa Pajambon 1 [erosi ringan (18,67 ton/ha/tahun)], di Desa Pajambon 2 [erosi berat (184,40 ton/ha/tahun)], dan di Desa Pajambon 3 [erosi sangat berat (210,00 ton/ha/tahun)]. Akumulasi tingkat kerusakan tersebut, tentunya berdampak pada sebaran jenis tanaman, baik dari distribusi maupun keragamannya, sehingga perlu adanya monitoring dan evaluasi dalam penggunaan lahan, sehingga perlu adanya pemberdayaan masyarakat, dalam membangun dan mengembangkan pola konservasi lahan secara kolaboratif serta berkelanjutan. Penelitian lanjutan masih perlu dilakukan terutama terkait deteksi dini kerusakan lahan dan luasnya lokasi penelitian di kawasan kab. Kuningan. Selain itu, penelitian tentang dinamika kepentingan masyarakat terkait aspek ekonomi dan pemanfaatan sumber daya lingkungan menarik untuk dikaji lebih lanjut.

\section{Ucapan Terima Kasih}

Penelitian ini telah dibantu oleh beberapa pihak yaitu Badan Pengelolaan Lingkungan Hidup Daerah (BPLHD) Kabupaten Kuningan, Perpustakaan Institut Pertanian Bogor (IPB) dan PT. Shiddiq Sarana Mulya

\section{Daftar Pustaka}

Agarwala, M., Atkinson, G., Fry, B. P., Homewood, K., Mourato, S., Rowcliffe, J. M., ... \& Milner-Gulland, E. J. (2014). Assessing the relationship between human well-being and ecosystem services: a review of frameworks. Conservation and Society, 12(4), 437. Available online: http://www.springerlink.com/index/T26V03555740502V.pdf

Akowuah, P. (2012). Promoting Conservation Agriculture Approaches for Sustainable Agricultural Production through Capacity Building of Field Extension Agents. Journal of Developments in Sustainable Agriculture, 7(2), 129-133. Available online: https://www.jstage.jst.go.jp/article/jdsa/7/2/7_129/_article/-char/ja/

Arifah, A. (2016). Reklasifikasi Iklim Jawa Barat. Available online: http://repository.ipb.ac.id/handle/123456789/85976 
Arisandi, G., Arifandi, J. A., \& Sudibya, J. 2015. Studi Faktor Penyebab Kerusakan Tanah Di Daerah Aliran Sungai (DAS). Available online: http://repository.unej.ac.id/handle/123456789/70943

As-Syakur, A. (2011). Perubahan penggunaan lahan di Provinsi Bali. Ecotrophic: Journal of Environmental Science, 6(1), 1-7. Available online: http://ojs.unud.ac.id/index.php/ECOTROPHIC/article/view/13316

Berendse, F., van Ruijven, J., Jongejans, E., \& Keesstra, S. (2015). Loss of plant species diversity reduces soil erosion resistance. Ecosystems, 18(5), 881-888. Available online: http://link.springer.com/article/10.1007/s10021-015-9869-6

BPS Kabupaten Kuningan (2015). Kuningan Dalam Angka tahun 2015.

Costantini, E. A. (2016). Soil indicators to assess the effectiveness of restoration strategies in dryland ecosystems. Solid Earth, 7(2), 397. Available online: http://search.proquest.com/openview/0b14230f74a7012393efcaf312f6c7d2/1?pqorigsite $=$ gscholar $\& \mathrm{cbl}=2037675$

Fahma, W, dan Kristiyanto. 2016. Penguatan Home garden sebagai garda ketahanan pangan berbasis peta kesesuaian lahan dengan aplikasi Maxent, di Kota Tanggerang Selatan. Laporan hasil penelitian (Unpublished), UIN Jakarta.

Ford, H., Garbutt, A., Ladd, C., Malarkey, J., \& Skov, M. W. (2016). Soil stabilization linked to plant diversity and environmental context in coastal wetlands. Journal of vegetation science, 27(2), 259-268. Available online: http://onlinelibrary.wiley.com /doi/10.1111/jvs.12367/full

Francis, C. A., \& Porter, P. (2011). Ecology in sustainable agriculture practices and systems. Critical reviews in plant sciences, 30(1-2), 64-73. Available online: http://www.tandfonline.com/doi/abs/10.1080/07352689.2011.554353

Govers, G., Merckx, R., Wesemael, B. V., \& Oost, K. V. (2017). Soil conservation in the 21st century: why we need smart agricultural intensification. Soil, 3(1), 45-59. Available online: http://www.soil-journal.net/3/45/2017/soil-3-45-2017-metrics.html

Gunawan, G., Hidayat, K., \& Purnomo, M. (2013). Penerapan Inovasi Teknologi Ramah Lingkungan Pada Komunitas Petani Sayuran (Studi di Desa Tawangargo, Kecamatan Karangploso, Kabupaten Malang). Habitat, 24(1), 20-31. Available online: http://www.habitat.ub.ac.id/index.php/habitat/article/view/98

Karami, R., Mehrabi, H., \& Ariapoor, A. (2015). The effect of altitude and slope in the species diversity of herbaceous plants (case study: watershed Miandar QarootagGilangharb). Journal of Applied Environmental and Biological Sciences, 5(7), 197-204. Available online: https://www.textroad.com/pdf/JAEBS/J.\%20Appl.\%20Environ. \%20Biol.\%20Sci.,\%205(7)197-204,\%202015.pdf

Kumar, P. (2013). The mining activity and its impact on plant biodiversity: A case study at Bhiwani open cast mining zones-Haryana, India. Asian Journal of Plant Science and Research, 3(6), 78-83. Available online: http://www.imedpub.com/articles/the-miningactivity-and-its-impact-on-plant-biodiversitya-case-study-at-bhiwani-open-cast-miningzonesharyana-india.pdf

Laurance, W. F., Sayer, J., \& Cassman, K. G. (2014). Agricultural expansion and its impacts on tropical nature. Trends in ecology \& evolution, 29(2), 107-116. Available online: http://www.sciencedirect.com/science/article/pii/S0169534713002929 
Lima, C. A. D., Palácio, H. A. D. Q., Andrade, E. M. D., dos Santos, J. C., \& Brasil, P. P. (2013). Characteristics of rainfall and erosion under natural conditions of land use in semiarid regions. Revista Brasileira de Engenharia Agrícola e Ambiental, 17(11), 12221229. Available online: http://www.scielo.br/scielo.php?pid=S141543662013001100014\&script=sci_arttext\&tlng=pt

Maier, D. (2015). The Great Myth: Why population growth does not necessarily cause environmental degradation and poverty. The Public Sphere, 150-158. Available online: https://pdfs.semanticscholar.org/8caf/6c572acb2874189ec7097194d9fda76eb4b7.pdf

McBratney, A., Field, D. J., \& Koch, A. (2014). The dimensions of soil security. Geoderma, 213, 203-213. Available online: http://www.sciencedirect.com/science/article/pii/S0016706113002954

Mohamadi, M. A., \& Kavian, A. (2015). Effects of rainfall patterns on runoff and soil erosion in field plots. International Soil and Water Conservation Research, 3(4), 273-281.

Montgomery, D. R. (2007). Soil erosion and agricultural sustainability. Proceedings of the National Academy of Sciences, 104(33), 13268-13272. Available online: http://www.pnas.org/content/104/33/13268.short

Pimentel, D., \& Burgess, M. (2013). Soil erosion threatens food production. Agriculture, 3(3), 443-463. Available online: http://www.mdpi.com/2077-0472/3/3/443/htm

Qiu, Y., Fu, B., Wang, J., \& Chen, L. (2001). Spatial variability of soil moisture content and its relation to environmental indices in a semi-arid gully catchment of the Loess Plateau, China. Journal of Arid Environments, 49(4), 723-750. Available online: http://www.sciencedirect.com/science/article/pii/S0140196301908286

Redpath, S. M., Young, J., Evely, A., Adams, W. M., Sutherland, W. J., Whitehouse, A., ... \& Gutierrez, R. J. (2013). Understanding and managing conservation conflicts. Trends in ecology \& evolution, 28(2), 100-109. Available online: http://www.sciencedirect.com/science/article/pii/S0169534712002169

Sarah, P., Zhevelev, H. M., \& Atar, O. Z. (2015). Urban park soil and vegetation: effects of natural and anthropogenic factors. Pedosphere, 25(3), 392-404. Available online: http://www.sciencedirect.com/science/article/pii/S1002016015300072

Sensoy, H., \& Kara, Ö. (2014). Slope shape effect on runoff and soil erosion under natural rainfall conditions. iForest-Biogeosciences and Forestry, 7(2), 110. Available online: http://www.sisef.it/iforest/contents/?id=ifor0845-007

Setyaningrum, B. R. A. (2015). Kajian Status Kerusakan Tanah pada Lahan Pertanian di Kecamatan Denpasar Selatan (Doctoral dissertation, Universitas Udayana). Available online: http://erepo.unud.ac.id/id/eprint/8214

Sinha, R. K., Herat, S., Chauhan, K., \& Valani, D. (2009). Special Issue: Vermiculture \& sustainable agriculture. American-Eurasian Journal of Agricultural and Environmental Science, 5(S). Available online: https://www.cabdirect.org/cabdirect/abstract/20093259134

Teshome, A., de Graaff, J., \& Stroosnijder, L. (2014). Evaluation of soil and water conservation practices in the north-western Ethiopian highlands using multi-criteria analysis. Frontiers in Environmental science, 2, 60. Available online: http://journal.frontiersin .org/article/10.3389/fenvs.2014.00060

Wang, J., Wang, H., Cao, Y., Bai, Z., \& Qin, Q. (2016). Effects of soil and topographic factors on vegetation restoration in opencast coal mine dumps located in a loess area. Scientific reports, 6. Available online: https:/www.ncbi.nlm.nih.gov/pmc/articles/PMC4768095/ 
Zhu, Y. G., \& Meharg, A. A. (2015). Protecting global soil resources for ecosystem services. Ecosystem Health and Sustainability, 1(3), 1-4. Available online: http://onlinelibrary.wiley.com/doi/10.1890/EHS15-0010.1/full

Zornoza, R., Acosta, J. A., Bastida, F., Domínguez, S. G., Toledo, D. M., \& Faz, A. (2015). Identification of sensitive indicators to assess the interrelationship between soil quality, management practices and human health. Soil, 1(1), 173. Available online: http://search.proquest.com/openview/7dee7f5f67661803e125d15239ab4dda/1 ?pqorigsite $=$ gscholar $\& \mathrm{cbl}=2040561$ 